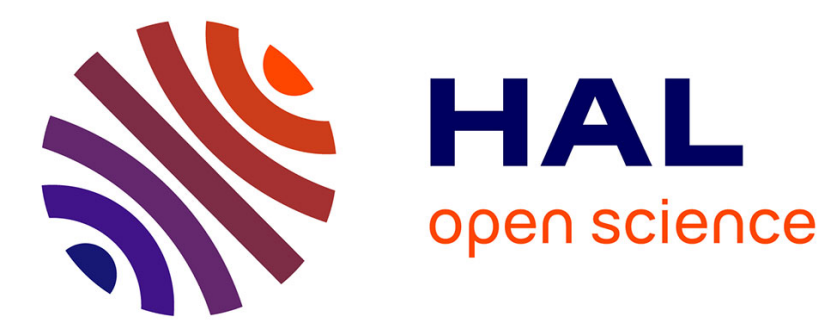

\title{
Thiolation of NHC-boranes: influence of the substitution at boron
}

\author{
Anne-Laure Vallet, Emmanuel Lacote
}

\section{To cite this version:}

Anne-Laure Vallet, Emmanuel Lacote. Thiolation of NHC-boranes: influence of the substitution at boron. Organic \& Biomolecular Chemistry, 2019, 17, pp.4234-4237. 10.1039/c9ob00578a . hal02104323

\section{HAL Id: hal-02104323 \\ https://univ-lyon1.hal.science/hal-02104323}

Submitted on 19 Apr 2019

HAL is a multi-disciplinary open access archive for the deposit and dissemination of scientific research documents, whether they are published or not. The documents may come from teaching and research institutions in France or abroad, or from public or private research centers.
L'archive ouverte pluridisciplinaire HAL, est destinée au dépôt et à la diffusion de documents scientifiques de niveau recherche, publiés ou non, émanant des établissements d'enseignement et de recherche français ou étrangers, des laboratoires publics ou privés. 


\title{
Thiolation of NHC-Boranes: Influence of the Substitution at Boron
}

Received 00th January 20xx,

\author{
Anne-Laure Vallet, ${ }^{a}$ Emmanuel Lacôte ${ }^{*^{b^{\dagger}}}$
}

Accepted 00th January 20xx

DOI: $10.1039 / \times 0 \times x 00000 x$

Several N-Heterocyclic Carbene (NHC)-boryl sulfides with Bsubstituents were prepared. The added steric hindrance leads to much improved selectivities as only the NHC-boryl mono-sulfides were obtained. The B-substituted NHC-boranes are also conducive to more selective $\mathrm{S}$ to $\mathrm{N}$ NHC-boryl shift, provided that the NHC used is not too sterically demanding.

The complexation of boranes with Lewis basic carbenes such as $\mathrm{N}$-heterocyclic carbenes (NHCs), ${ }^{1}$ mesoionic carbenes (MICs), ${ }^{2}$ or cyclic alkyl amino carbenes (CAACs) ${ }^{3}$ enables new reactivities owing to the stabilization by the carbenes of reactive intermediates, in particular boron-centered radicals. ${ }^{4}$ As a consequence NHC-boranes and related structures have emerged as great tools for radical organic synthesis. ${ }^{5-8}$ Thus, it is of primary importance to understand the reactivity of carbene boranes, so that one can discover new reactions they can be used in.

In particular, we showed that NHC-boryl radicals could undergo homolytic substitutions, thus leading to NHC-boryl sulfides and disulfides. ${ }^{9}$ A likely ionic pathway was also evidenced, which delivered the same final products, via a hydride transfer from the NHC-boranes to the disulfides, followed by nucleophilic addition of the thiolate generated to the resulting borenium intermediates. ${ }^{10}$ Most interestingly, the resulting NHC-boryl sulfides can be used as tin hydride surrogates in radical reactions ${ }^{11}$ and Type I photo-initiators. ${ }^{12}$ Both the ionic and radical reactions exhibit a large scope with regard to the NHCs and aryldisulfides, but we only considered $\mathrm{BH}_{3}$-adducts. Both the mono and bis-sulfides were generally observed. The reactions were optimized to deliver mostly one or the other of the products, but in some cases the adducts could not be separated, and the selectivities were not

\footnotetext{
a. ICSN-CNRS, Bâtiment 27, 1 avenue de la Terrasse, 91198 Gif-sur-Yvette Cedex, France.

b. Univ Lyon, Université Claude Bernard Lyon 1, CNRS, CNES, ArianeGroup, LHCEP, Bât. Raulin, 2 rue Victor Grignard, F-69622 Villeurbanne, France. E-mail : emmanuel.lacote@univ-lyon1.fr

† This work was supported by CNRS. A.-L. V. thanks ICSN for a doctoral stipend. Electronic Supplementary Information (ESI) available: Description of procedures and all new NHC-borane compounds, including spectra. See DOI: $10.1039 / x 0 \times x 00000 x$
}

excellent. In this context, we decided to examine the influence of a pre-installed subtituent at boron. We reasoned that a steric lock could lead to more selective reactions. We report herein that this is indeed the case.

For this study we chose to work with aryl-substituted derivatives in order to have structurally similar groups. We thus selected four different aryl rings, with substituents ranging from strongly electron-withdrawing groups $\left(4-\mathrm{CF}_{3}\right)$ to strongly donating (MeO). Two NHCs were selected: the sterically demanding IPr and the smaller IMe. We examined two sets of conditions (see Table 1). In a typical thermal reaction, the NHC-(phenyl)borane was heated overnight at $45^{\circ} \mathrm{C}$ in deoxygenated benzene in the presence of one equivalent of diphenyldisulfide (Table 1 , Entry 1 , conditions $\Delta$ ). In a typical photochemical reaction (Entry 2, hv), the same reagents were irradiated at room temperature for 30 minutes using an OmniCure ${ }^{\circledR} \mathrm{S} 1000$ apparatus. It is expected that the thermal reaction proceed via an ionic mechanism, ${ }^{10}$ while the photochemical reaction proceeds via a radical mechanism. ${ }^{9}$ The thermal reaction of the phenyl-substituted NHC-Borane DiMe-Imd- $\mathrm{BH}_{2} \mathrm{Ph}$ with diphenyl disulfide led to adduct $\mathbf{1 a}$ in $51 \%$ yield (entry 1 ). With di-(2-naphthyl) disulfide (resp. di-(4methoxy) disulfide), it delivered 1b (resp. 1c) in $80 \%$ (resp. $55 \%$ ) yield (entries 3 and 5). Noticeably, the corresponding photochemical reactions gave $\mathbf{1 a}$ and $\mathbf{1 b}$ in lower yields $(19 \%$ vs. 51 , entry $2 ; 30 \%$ vs. $80 \%$, entry 4 ) but $1 \mathrm{c}$ was obtained in $72 \%$ yield, better than the thermal reaction (entry 6). Considering that the thermal yields were on average better that the photochemical ones, we decided to examine the scope of the reaction only under thermal conditions.

For DiMe-Imd- $\mathrm{BH}_{2}\left[\left(4-\mathrm{CF}_{3}\right)-\mathrm{C}_{6} \mathrm{H}_{4}\right]$ the NHC-boryl sulfides were obtained in yields similar to those obtained with the phenylsubstituted substrate ( $44 \%$ for 1 d, entry $7 ; 82 \%$ for 1 e, entry 8 ; $44 \%$ for 1f, entry 9). and electron-donating (4-OMe) substituents at boron are compatible with the reaction. Alternatively, the electron-donating-substituted NHC-borane DiMe-Imd- $\mathrm{BH}_{2}\left[(4-\mathrm{OMe})-\mathrm{C}_{6} \mathrm{H}_{4}\right]$ delivered adducts $1 \mathrm{j}-\mathrm{I}$ in $62 \%$ yields (resp. 42\%, 75\%, entries 13-15). Curiously, the $\mathrm{m}-\mathrm{Br}$ substituted NHC-Borane DiMe-Imd- $\mathrm{BH}_{2}\left[(3-\mathrm{Br})-\mathrm{C}_{6} \mathrm{H}_{4}\right]$ was a 
poor substrate, as 1g-i were obtained in rather poor yields (29\%, $27 \%$ and $8 \%$, respectively, entries $10-12$ ).

We next varied the NHC and chose the bulky IPr to replace the small IMe (entries 16-20). No reaction took place under the thermal conditions (entries 16 and 18). The photochemical conditions delivered NHC-boryl mono-sulfides $\mathbf{1 m}$ (from diphenyl disulfide, $20 \%$, entry 17 ) and 1 n (from di-(4-methoxy) disulfide, $37 \%$, entry 20 ). The reaction with di-(2-naphthyl) disulfide only led to degradation (entry 19). Overall the yields were lower than those obtained in the same conditions with DiMe-Imd- $\mathrm{BH}_{2} \mathrm{Ph}$.

Table 1. Scope of the Preparation of NHC-Boryl Sulfides from B-Substituted NHCBoranes.

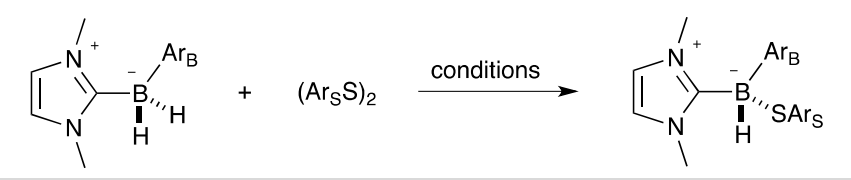

\begin{tabular}{|c|c|c|c|c|}
\hline Entry & $\mathrm{Ar}_{\mathrm{B}}$ & $\mathrm{Ar}_{\mathrm{S}}$ & Cond. ${ }^{a}$ & $\begin{array}{l}\text { Product, } \\
\text { Yield (\%) }\end{array}$ \\
\hline 1 & $\mathrm{Ph}$ & $\mathrm{Ph}$ & $\Delta$ & 1a, 51 \\
\hline 2 & $\mathrm{Ph}$ & $\mathrm{Ph}$ & hv & 1a, 19 \\
\hline 3 & $\mathrm{Ph}$ & 2-Naphth & $\Delta$ & 1b, 80 \\
\hline 4 & $\mathrm{Ph}$ & 2-Naphth & hv & 1b, 30 \\
\hline 5 & $\mathrm{Ph}$ & 4- $\mathrm{MeO}\left(\mathrm{C}_{6} \mathrm{H}_{4}\right)$ & $\Delta$ & 1c, 55 \\
\hline 6 & $\mathrm{Ph}$ & 4- $\mathrm{MeO}\left(\mathrm{C}_{6} \mathrm{H}_{4}\right)$ & hv & 1c, 72 \\
\hline 7 & $4-\mathrm{F}_{3} \mathrm{C}\left(\mathrm{C}_{6} \mathrm{H}_{4}\right)$ & $\mathrm{Ph}$ & $\Delta$ & 1d, 44 \\
\hline 8 & $4-\mathrm{F}_{3} \mathrm{C}\left(\mathrm{C}_{6} \mathrm{H}_{4}\right)$ & 2-Naphth & $\Delta$ & $1 e, 82$ \\
\hline 9 & $4-\mathrm{F}_{3} \mathrm{C}\left(\mathrm{C}_{6} \mathrm{H}_{4}\right)$ & 4- $\mathrm{MeO}\left(\mathrm{C}_{6} \mathrm{H}_{4}\right)$ & $\Delta$ & 1f, 44 \\
\hline 10 & $3-\mathrm{Br}\left(\mathrm{C}_{6} \mathrm{H}_{4}\right)$ & $\mathrm{Ph}$ & $\Delta$ & 1g, 29 \\
\hline 11 & 3- $\mathrm{Br}\left(\mathrm{C}_{6} \mathrm{H}_{4}\right)$ & 2-Naphth & $\Delta$ & 1h, 27 \\
\hline 12 & 3- $\mathrm{Br}\left(\mathrm{C}_{6} \mathrm{H}_{4}\right)$ & 4- $\mathrm{MeO}\left(\mathrm{C}_{6} \mathrm{H}_{4}\right)$ & $\Delta$ & $1 i, 8$ \\
\hline 13 & 4- $\mathrm{MeO}\left(\mathrm{C}_{6} \mathrm{H}_{4}\right)$ & $\mathrm{Ph}$ & $\Delta$ & $1 \mathrm{j}, 62$ \\
\hline 14 & 4- $\mathrm{MeO}\left(\mathrm{C}_{6} \mathrm{H}_{4}\right)$ & 2-Naphth & $\Delta$ & $1 k, 42$ \\
\hline 15 & 4-MeO $\left(\mathrm{C}_{6} \mathrm{H}_{4}\right)$ & 4- $\mathrm{MeO}\left(\mathrm{C}_{6} \mathrm{H}_{4}\right)$ & $\Delta$ & 1I, 75 \\
\hline $16^{\mathrm{b}}$ & $\mathrm{Ph}$ & $\mathrm{Ph}$ & $\Delta$ & $-{ }^{c}$ \\
\hline $17^{\mathrm{b}}$ & $\mathrm{Ph}$ & $\mathrm{Ph}$ & hv & $1 \mathrm{~m}, 20$ \\
\hline $18^{b}$ & $\mathrm{Ph}$ & 2-Naphth & $\Delta$ & $-^{c}$ \\
\hline $19^{b}$ & $\mathrm{Ph}$ & 2-Naphth & hv & $--^{d}$ \\
\hline $20^{b}$ & $\mathrm{Ph}$ & 4- $\mathrm{MeO}\left(\mathrm{C}_{6} \mathrm{H}_{4}\right)$ & hv & 1n, 37 \\
\hline
\end{tabular}

${ }^{\text {a }}$ Conditions: $45^{\circ} \mathrm{C} ; \mathrm{PhH}$, overnight $(\Delta)$ or $\mathrm{PhH}, \mathrm{rt}$, Omnicure ${ }^{\circledR}$ irradiation (hv); ${ }^{b}$ Carbene is Dipp-(Imd); ${ }^{c}$ no reaction; ${ }^{d}$ degradation

Several conclusions can be drawn from the previous study.

- The formation of NHC-boryl sulfides is sensitive to steric hindrance. The reactions require somewhat harsher conditions that the same ones using $\mathrm{BH}_{3}$-based Lewis pairs. There is a price to pay as the yields are smaller but there is a strong advantage, as only mono-adducts are obtained, under both thermal and photochemical conditions. The selectivity is better, which is especially interesting as the adducts obtained are those more difficult to isolate pure from the unsubstituted NHC-boranes.

- The homolytic reaction suffers more from steric hindrance than the (likely) ionic reaction. The radical reaction is a bimolecular homolytic substitution, which suffers strongly from steric congestion. The key elementary step in the thermal reaction is probably a hydride transfer from the NHC-borane.
This generates a borenium intermediate, which is intercepted by the thiolate generated. Our observations show that this suffers less from steric congestion than the $\mathrm{S}_{\mathrm{H}} 2$.

- The nature of the substituent at boron has a stronger influence over reactivity than that of the disulfide. However, there is no clear relation between the electronic nature of the substituent at boron and the reactivity.

- In all cases, steric hindrance at the NHC part of the Lewis pair is a very strong factor. It totally shuts down the ionic reaction. The radical substitution goes on somewhat, but is very low yielding, and it is accompanied by a lot of degradation.

Our next step was to examine whether the 1,3 NHC-boryl shift from sulfur to nitrogen we discovered(12) would still be operant. Indeed, on the unsubstituted NHC-boranes, the bulky NHC IPr prevented the shift to take place. We selected two disulfides suitable with the rearrangement, bis(mercaptobenzothiazolyl) disulfide and bis(1phenyltetrazolyl) disulfide.

Scheme 1. 1,3-NHC boryl shift with B-substituted NHC-borane and bis(mercaptobenzothiazolyl) disulfide

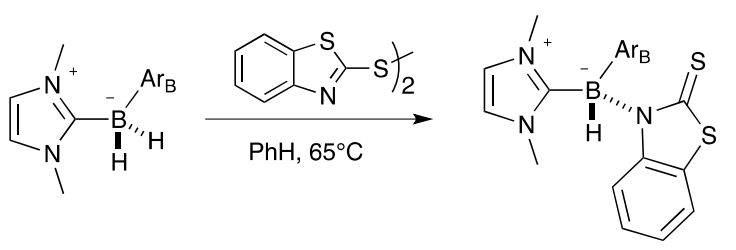

$$
\begin{aligned}
& \operatorname{Ar}_{\mathrm{B}}= \mathrm{Ph}: \mathbf{2 a}, 62 \% \\
& \mathrm{Ar}_{\mathrm{B}}=p-\mathrm{F}_{3} \mathrm{C}\left(\mathrm{C}_{6} \mathrm{H}_{4}\right): \mathbf{2 b}, 23 \%+8 \% \text { monosulfide } \\
& \quad+8 \% \\
& \operatorname{Ar}_{\mathrm{B}}= m-\mathrm{Br}\left(\mathrm{C}_{6} \mathrm{H}_{4}\right): \mathbf{2 c}, 34 \% \\
& \mathrm{Ar}_{\mathrm{B}}=p-\operatorname{MeO}\left(\mathrm{C}_{6} \mathrm{H}_{4}\right): \mathbf{2 d}, 67 \%
\end{aligned}
$$

The reaction of variously substituted B-aryl NHC-boranes derived from the IMe carbene and bis (mercaptobenzothiazolyl) disulfide proceeded at $65^{\circ} \mathrm{C}$ in benzene (Scheme 1). Gratifyingly, in all cases the monosubstituted B-amino NHC-borane was isolated in modest (23\% for $\mathbf{2 b}, \mathbf{3 4 \%}$ for $\mathbf{2 c}$ ) to good yields ( $62 \%$ for $\mathbf{2 a}, 67 \%$ for $\mathbf{2 d}$ ). In the case of the $p$-trifluoromethyl substituted aryl borane derivative, $8 \%$ of monosulfide were also isolated, and not in the other cases. This again suggests that the $\mathrm{B}-\mathrm{N}$ products come from rearrangement of the corresponding $B-S$ adducts initially formed.(12) Adducts $\mathbf{2 a - d}$ are the first examples of Bsubstituted amino NHC-boranes.

The reactions worked slightly less efficiently in the case of bis(1-phenyltetrazolyl) disulfide (Scheme 2). Despite the average yields $(23-58 \%$ for $\mathbf{3 a - d})$, only the corresponding mono-substituted amino NHC-boranes were again isolated except for $\mathbf{3 b}$ where a minor amount $(10 \%)$ of the mixed bisadduct was also isolated.

The rearrangement is not limited to imidazolydinene-boranes, as triazolylidene-borane $3 e$ was obtained in $56 \%$. Note that all derivatives 3a-e have a high number of nitrogen atoms, which makes them potentially pyrotechnic. We however experienced no problem in handling them. Despite the high nitrogen (and boron) content, there are enough heavier atoms to prevent 
explosions. Nonetheless, adequate care should always be exercised when handling these products.

Scheme 2. 1,3-NHC boryl shift with B-substituted NHC-borane and bis(1phenyltetrazolyl) disulfide.

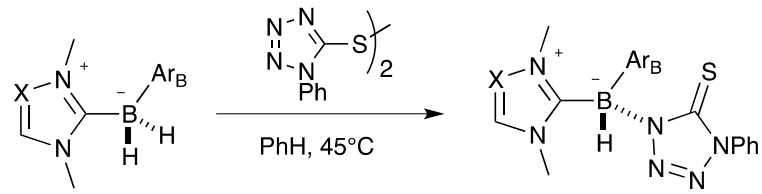

$$
\begin{aligned}
& \mathrm{X}=\mathrm{CH}, \mathrm{Ar}_{\mathrm{B}}=\mathrm{Ph}: \mathbf{3 a}, 58 \% \\
& \mathrm{X}=\mathrm{CH}, \mathrm{Ar}_{\mathrm{B}}=p-\mathrm{F}_{3} \mathrm{C}\left(\mathrm{C}_{6} \mathrm{H}_{4}\right): \mathbf{3 b}, 23 \% \\
& \quad \quad(\text { see text) } \\
& \mathrm{X}=\mathrm{CH}, \mathrm{Ar}_{\mathrm{B}}=m-\mathrm{Br}\left(\mathrm{C}_{6} \mathrm{H}_{4}\right): \mathbf{3 c}, 46 \% \\
& \mathrm{X}=\mathrm{CH}, \mathrm{Ar}_{\mathrm{B}}=p-\mathrm{MeO}\left(\mathrm{C}_{6} \mathrm{H}_{4}\right): \mathbf{3 d}, 39 \% \\
& \mathrm{X}=\mathrm{N}, \mathrm{Ar}_{\mathrm{B}}=\mathrm{Ph}: \mathbf{3 e}, 56 \%
\end{aligned}
$$

Finally, the presence of the very congested IPr on the borane blocked the rearrangement, in both the benzothiazole and the mercapto tetrazole series (Scheme 3). In both cases, the NHC boryl monosulfides (4a and $\mathbf{4 b}$ ) were obtained respectively in $42 \%$ and $64 \%$ yields.

Scheme 3. Absence of 1,3-NHC boryl shift with B-substituted IPr-boranes

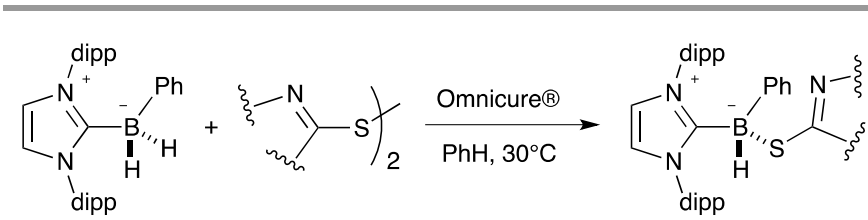

$\operatorname{dipp}=2,6-\mathrm{Di}-\mathrm{iPr}-\mathrm{C}_{6} \mathrm{H}_{4}$ BZT (see Sch. 1): $\mathbf{4 a}, 42 \%$
SPT (see Sch. 2): $\mathbf{4 b}, 64 \%$

Overall, the NHC-boryl shift is also very selective. That supports the hypothesis that the NHC-boryl sulfides are formed first selectively, and rearrange (or not) in a consecutive mechanistical step.

\section{Conclusions}

To conclude, we could extend the synthesis of NHC-boryl sulfides to B-substituted boranes. The added steric hindrance at the boron atom makes the reactions more difficult and slightly lower yielding. However it allows much improved selectivities as only the NHC-boryl mono-sulfides are obtained. When the disulfide employed are suitable to $\mathrm{S}$ to $\mathrm{N} \mathrm{NHC}$-boryl shift, i. e. when they have an $\alpha-\mathrm{C}=\mathrm{N}$ bond in a 5-membered ring, the corresponding amino NHC-boranes are formed, except when a highly congested carbene is present, which shuts down the rearrangement but not the thiolation. All NHCboranes isolated are new. They are all stable despite the steric hindrance around the boron atom, which could lead to frustrated Lewis pairs. ${ }^{13}$ We are now focusing on studying the reactivity of the compound, in particular the influence of the aryl group on the strength of the B-S bond, and its ability to be an antenna for photochemical cleavage of the same bond. Finally, the NHC-boranes obtained are stereogenic at boron, ${ }^{14}$ which might be interesting for stereochemical applications.

\section{Conflicts of interest}

There are no conflicts to declare.

\section{Notes and references}

1 D. P. Curran, A. Solovyev, M. Makhlouf Brahmi, L. Fensterbank, M. Malacria, E. Lacôte, Angew. Chem. Int. Ed., 2011, 50, 10294.

2 P. Eisenberger, B. P. Bestvater, E. C. Keske, C. M. Crudden, Angew. Chem. Int. Ed. 2015, 54, 2467; L. B. de Oliveira Freitas, P. Eisenberger, C. M. Crudden, Organometallics 2013, 32, 6635.

3 G. D. Frey, J. D. Masuda, B. Donnadieu, G. Bertrand, G. Angew. Chem. Int. Ed. 2010, 49, 9444.

4 S.-H. Ueng, A. Solovyev, X. Yuan, S. J. Geib, L. Fensterbank, E. Lacôte, M. Malacria, M. Newcomb, J. C. Walton, D. P. Curran, J. Am. Chem. Soc. 2009, 131, 11256; J. C. Walton, M. Makhlouf Brahmi, J. Monot, L. Fensterbank, M. Malacria, D. P. Curran, E. Lacôte, J. Am. Chem. Soc. 2011, 133, 10312; S. Telitel, A.-L.Vallet, D. M. Flanigan, B. Graff, F. Morlet-Savary, T. Rovis, J. Lalevée, E. Lacôte, Chem. Eur. J. 2015, 21, 13772; P. Bissinger, H. Braunschweig, A. Damme, I. Krummenacher, A. K. Phukan, K. Radacki, S. Sugawara, Angew. Chem. Int. Ed. 2014, 53, 7360; R. Bertermann, H. Braunschweig, R. D. Dewhurst, C. Hoerl, T. Kramer, I. Krummenacher, Angew. Chem. Int. Ed. 2014, 53, 5453; M. F. Silva Valverde, P. Schweyen, D. Gisinger, T. Bannenberg, M. Freytag, C. Kleeberg, M. Tamm, Angew. Chem. Int. Ed. 2017, 56, 1135; D. K. Roy, I. Krummenacher, T. E. Stennett, C. Lenczyk, T. Thiess, H. Braunschweig, E. Welz, B. Engels, Chem. Commun. 2018, 54, 9015; D. Subervie, B. Graff, S. Nerkar, D. P. Curran, J. Lalevée, E. Lacôte, Angew. Chem. Int. Ed. 2018, 57, 10251.

5 H-atom donors: S.-H. Ueng, M. Makhlouf Brahmi, É. Derat, L. Fensterbank, E. Lacôte, M. Malacria, D. P. Curran, J. Am. Chem. Soc. 2008, 130, 10082; X. Pan, E. Lacôte, J. Lalevée, D. P. Curran, J. Am. Chem. Soc. 2012, 134, 5669.

6 Polymerization initiators: M.-A. Tehfe, M. Makhlouf Brahmi, J. P. Fouassier, D. P. Curran, M. Malacria, L. Fensterbank, E. Lacôte, J. Lalevée, Macromolecules 2010, 43, 2261; M.-A. Tehfe, J. Monot, M. Malacria, L. Fensterbank, J. P. Fouassier, D. P. Curran, E. Lacôte, J. Lalevée, ACS Macro Lett. 2012, 1, 92; J. Lalevée, S. Telitel, M.-A. Tehfe, J. P. Fouassier, D. P. Curran, E. Lacôte, Angew. Chem. Int. Ed. 2012, 51, 5958; B. Aubry, D. Subervie, M. Lansalot, E. Bourgeat-Lami, B. Graff, F. Morlet-Savary, C. Dietlin, J. P. Fouassier, E. Lacôte, J. Lalevée, Macromolecules 2018, 51, 9730; F. Le Quéméner, D. Subervie, F. Morlet-Savary, J. Lalevée, M. Lansalot, E. Bourgeat-Lami, E. Lacôte, Angew. Chem. Int. Ed. 2018, 57, 957.

7 Radical Hydroboration: M. Shimoi, T. Watanabe, K. Maeda, D. P. Curran, T. Taniguchi, Angew. Chem. Int. Ed. 2018, 57, 9485; N. Zhou, X.-A. Yuan, Y. Zhao, J. Xie, C. Zhu, Angew. Chem. Int. Ed. 2018, 57, 3990; J. Qi, F.-L. Zhang, Y.-S. Huang, A.-Q. Xu, S.-C. Ren, Z.-Y. Yi, Y.-F. Wang, Org. Lett. 2018, 20, 2360; W. Dai, T. R. McFadden, D. P. Curran, H. A. Früchtl, J. C. Walton, J. Am. Chem. Soc. 2018, 140, 15868; T. Watanabe, D. Hirose, D. P. Curran, T. Taniguchi, Chem. Eur. J. 2017, 23, 5404; S.-C. Ren, F.-L. Zhang, J. Qi, Y.-S. Huang, A.-Q. Xu, H.-Y. Yan, Y.-F. Wang, J. Am. Chem. Soc. 2017, 139, 6050.

8 Radical cyanation: T. Kawamoto, S. J. Geib, D. P. Curran, J. Am. Chem. Soc. 2015, 137, 8617.

9 X.Pan, A.-L. Vallet, S. Schweizer, K. Dahbi, B. Delpech, N. Blanchard, B. Graff, S. J. Geib, D. P. Curran, J. Lalevée, E. Lacôte, J. Am. Chem. Soc. 2013, 135,10484. 
10 A. Solovyev, Q. Chu, S. J. Geib, L. Fensterbank, M. Malacria, E. Lacôte, D. P. Curran, J. Am. Chem. Soc. 2010, 132, 15072.

11 X. Pan, J. Lalevée, E. Lacôte, D. P. Curran, Adv. Synth. Catal. 2013, 355, 3522.

12 S. Telitel, A.-L. Vallet, S. Schweizer, B. Delpech, N. Blanchard, F. Morlet-Savary, B. Graff, D. P. Curran, M. Robert, E. Lacôte, J. Lalevée, J. Am. Chem. Soc. 2013, 135, 16938.

13 P. A. Chase, D. W. Stephan, Angew. Chem. Int. Ed. 2008, 47 7433; b) D. Holschumacher, T. Bannenberg, C. G. Hrib, P. G. Jones, M. Tamm, Angew. Chem. Int. Ed. 2008, 47, 7428; c) Y. Hoshimoto, T. Kinoshita, M. Ohashi, S. Ogoshi, Angew. Chem. Int. Ed. 2015, 54, 11666; d) S. Kronig, E. Theuergarten, D. Holschumacher, T. Bannenberg, C. G. Daniliuc, P. G. Jones, M. Tamm, Inorg. Chem. 2011, 50, 7344.

14 D. Banerjee, C. Besnard, E. P. Kundig, Organometallics 2012, 31, 709. 